\title{
A case study about embodied energy in concrete and structural masonry buildings
}

\section{Un estudio de caso sobre la energía contenida en construcciones con estructuras de hormigón y de mampostería estructural}

\author{
Marco Aurelio Gonzalez Stumpf (Main and Contact Author) \\ Unisinos - PPGEC/MPArqUrb, Brasil \\ mgonzalez@unisinos.br \\ Av. Unisinos, 950 - PPGEC - 6B308 - São Leopoldo, RS, Brasil - 93022-000 \\ Marlova Piva Kulakowski \\ Unisinos - PPGEC, Brasil \\ marlovak@unisinos.br
}

\author{
Luciano G. Breitenbach \\ Unisinos - PPGEM, Brasil \\ velotek@ibest.com.br \\ Felipe Kirch \\ Baliza Empreendimentos Imobiliários Ltda, Brasil \\ felipekirch@sinos.net
}

\author{
Manuscript Code: 0221 \\ Date of reception/acceptation: 01 jan 2014 / 01 aug 2014
}

\begin{abstract}
Resumen
La industria de la construcción tiene una gran responsabilidad ambiental. Todos los materiales de construcción tienen impactos ambientales durante su proceso de producción, pero los diseñadores pueden elegir los materiales y técnicas de menor impacto entre las opciones viables. El objetivo de este trabajo es examinar la energía contenida en los materiales de dos alternativas constructivas tradicionales en la región de São Leopoldo, ciudad al sur de Brasil. Las opciones de construcción que se consideran son la estructura de hormigón armado y la mampostería estructural. El estudio fue desarrollado bajo investigación de un proyecto de vivienda social típico en la región. Se hice el cálculo de las cantidades de materiales y se calculó la energía contenida en ellos. Los resultados indicarón que la energía contenida en estos dos sistemas constructivos es de aproximadamente $1,72 \mathrm{GJ} . \mathrm{m}^{-2}$ y $1,26 \mathrm{GJ} . \mathrm{m}^{-2}$, respectivamente. Se puede concluir que el contenido de energía es menor en el sistema de mampostería estructural, con una reducción en torno a $1 / 4$ en relación con la opción del hormigón. Los resultados pueden ser utilizados para ayudar a las decisiones de diseño.
\end{abstract}

Palabras claves: Construcción civil; sostenibilidad; energía contenida; hormigón; mampostería

\section{Introduction}

The exploitation of natural resources is significantly reducing the reserves of natural materials around the world. It can be observed that the materials employed in construction have a great responsibility in the environmental impacts. There are several methods of environmental assessment. They are classified into three groups: embodied energy, life cycle analysis (LCA) and identification using more simplified procedures, such as LEED and BREAM (Roaf et al., 2012).

According to Roaf et al. (2012), all materials have some environmental impact and there are still no methods to accurately assess the total impact of a building. Even the analysis of individual materials is complex. For these authors, the embodied energy is one of the most important measures for evaluating environmental impact, precisely because the use of non-renewable energy is the main reason for the general

\begin{abstract}
Building industry has a large environmental responsibility. All common materials have environmental impacts during their production process, but designers may choice the materials and techniques with less impact among the viable options. The objective of this work is to examine embodied energy in materials of two traditional constructive alternatives, in the region of São Leopoldo, a city in southern Brazil. Construction options considered are the reinforced concrete structure and the structural masonry. The study was developed under investigation of a social housing project typical in the region. We calculate the amounts of materials and the energy contained in them. The results indicated that the energy embodied in these two constructive systems is approximately $1.72 \mathrm{GJ} \cdot \mathrm{m}^{-2}$ and $1.26 \mathrm{GJ} . \mathrm{m}^{-2}$ respectively. It may be concluded that the embodied energy is lower in the structural masonry system, with a reduction around to $1 / 4$ in relation to the reinforced concrete option. The results can be used to help design decisions.
\end{abstract}

Keywords: Civil construction; sustainability; embodied energy; concrete; masonry

environmental degradation (through the release of $\mathrm{CO}_{2}$; and some emissions, such as acid rain).

Significant amount of energy is consumed in the production, transportation and application of building materials. Thus, the choice of materials and components can be made based on the analysis of the energy used for its production, and those considered best materials that consume less energy in their production processes and application in construction. The incorporated energy can be defined as the amount of energy consumed for the production of a product, or a material or construction, and may be included the steps of extraction of raw material to the distribution of product on the market (GauzinMüller, 2002).

The energy consumed in the built environment can be divided into two categories: (i) the energy consumed in producing the building, including the energy required for production and transport of materials, assembly or application in the work, and 
(ii) energy required for operation and maintaining the building over the life cycle and for scrapping and removing residues. The two plots should be studied, and the design definitions on the choice of materials have impact on both. Furthermore, in the same country, there is a great difference in power consumption due to technological differences.

The objective of this work is to use the quantification of embodied energy to examine constructive alternatives in a third world context, presenting a comparative analysis between two alternatives of traditional buildings in southern Brazil. It was found that the masonry structural system has incorporated significantly less energy than the traditional structured concrete.

\section{Literature review}

Some studies point to different embodied energy building standards. Gao et al. (2001) examined three types of buildings in Japan, indicating about $2.38 \mathrm{GJ} . \mathrm{m}^{-2}$ for wooden buildings in traditional Japanese pattern, 2.65 GJ.m ${ }^{-2}$ for wood frame and $2.85 \mathrm{GJ} . \mathrm{m}^{-2}$ for steel frame. These authors calculated the energy reduction that would occur in these systems incorporated with the use of recycled, concluding that the gain would be about $10 \%$.

Thormark (2002) considered constructions in Sweden, consisting of four two-store houses, built with masonry and reinforced concrete slabs, obtaining energy for construction around to 5.53 GJ.m ${ }^{-2}$.

Venkatarama Reddy \& Jagadish (2003) studied cases of constructions in India. One of the alternatives studied is built with walls and roof with adobe blocks with vaulted roofs and adobe stabilized (with the use of cement and lime), reaching $1.61 \mathrm{GJ} . \mathrm{m}^{-2}$. The second alternative consists of structural masonry walls, floors and roof of reinforced concrete (reaching 2.92 GJ. $\mathrm{m}^{-2}$ ). Finally, they calculate the embodied energy in homes built with reinforced concrete structure and masonry walls, coming to $4.21 \mathrm{GJ} . \mathrm{m}^{-2}$.

Also in India, Chel \& Tiwari (2009) examined constructions very similar to the first option of Venkatarama Reddy \& Jagadish (2003), with adobe walls and vaulted roof burned blocks, reaching $1.99 \mathrm{GJ} . \mathrm{m}^{-2}$ for old buildings and $2.30 \mathrm{GJ} . \mathrm{m}^{-2}$ for renewed units. Asif, Muneer \& Kelley (2007) estimated embodied energy in two-story row houses in Scotland with concrete structure and wooden walls, finding $1.62 \mathrm{GJ} . \mathrm{m}^{-2}$.

In Chile, Muñoz et al. (2012) studied social housing composed by a story built on masonry and another story in wood. They found an embodied energy of $3.51 \mathrm{GJ} . \mathrm{m}^{-2}$. In relative figures, masonry and structure represent around $60 \%$ of embodied energy on these buildings.

In Brazil, there are some specific studies, such as those of Cybis \& Santos (2000) on masonry, Manfredini \& Sattler (2005) on ceramic bricks, and Taborianski \& Prado (2004) about water heating, but there is still a long way to go. Tavares (2006) is the author with more complete study in the country, calculating the total embodied energy for an actual building. The study by Lobo et al. (2009) indicates an embodied energy of $5.45 \mathrm{GJ} . \mathrm{m}^{-2}$ for the implementation of a public library, built with masonry, reinforced concrete structure and roof with ceramic tiles.

After Scheuer et al. (2003), different energies found for each type of steel ranging from 14 to $31 \mathrm{GJ} . \mathrm{m}^{-2}$, whereas other authors used the same energy factor for all existing types of steel construction. Moreover, there are variations in time and space, because the energy depends on the production process, which varies from one country to another, according to various technological and different energy matrices, for example.

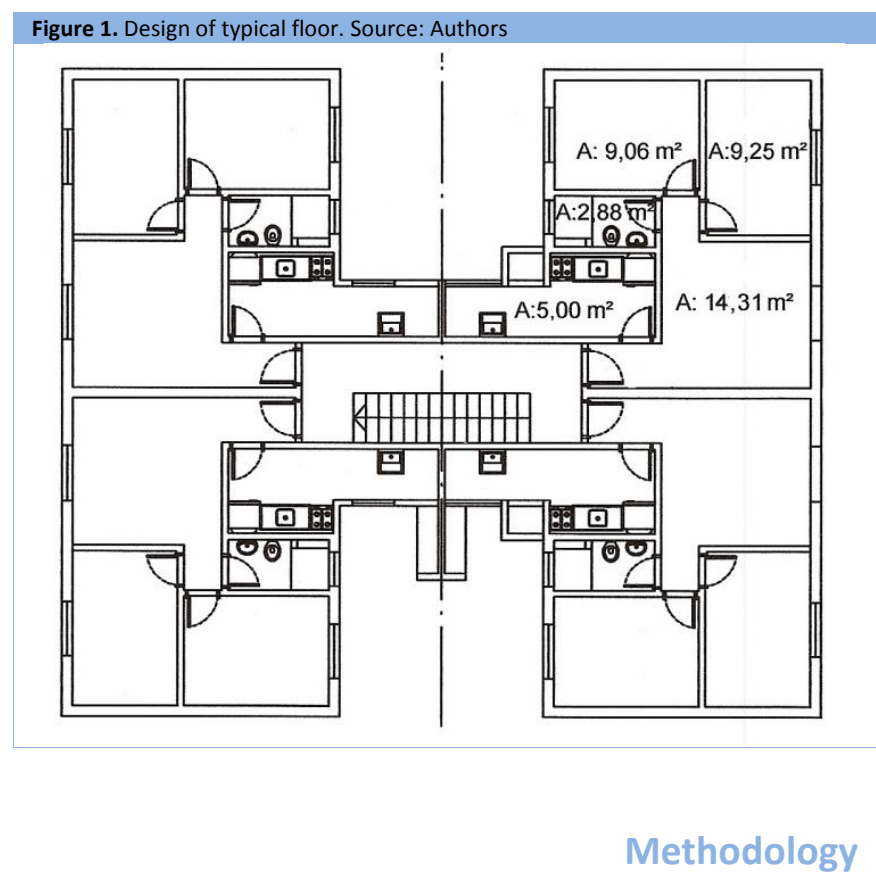

The work was developed based on a case study of a residential project, with the simulation performance of two alternative construction systems on the same basic design. We studied two traditional construction systems, (i) composed of reinforced concrete structure with masonry sealing closure of ceramic bricks and (ii) a structural masonry system with ceramic blocks. These two building systems correspond to those adopted in most vertical buildings executed in the region.

The study has a focus on the city of São Leopoldo, situated on southern Brazil (it have around 207 thousand inhabitants). The building studied consists of a social housing construction with four floors; each floor has four apartments with $38.75 \mathrm{~m}^{2}$ with a total of 16 apartments, plus $55.0 \mathrm{~m}^{2}$ of common use area, for vertical and horizontal movement, totaling a built area of 675.0 $\mathrm{m}^{2}$ per building. Figure 1 ilustrate basic design of floor.

\section{Building systems studied}

Reinforced concrete is the most used system in the region until now. This system has pillars, beams and slabs in reinforced concrete, with the masonry walls built with clay bricks. This 
system is well known and very used in the region. The second type on focus is structural masonry. It is a constructive process in which the walls play a structural function. Thus, the masonry has two functions, structural and closure of the building.

\section{Scope of review}

To make a comparison of the environmental impacts of both construction processes, it is necessary to characterize constructive steps which will be encompassed and what impacts will be assessed. In this case, we chose to examine only the embodied energy, not considering the emissions of greenhouse gases, for example.

Some elements are similar for both systems. In both cases, it was assumed the same kind of specification for internal and external coatings, flooring, waterproofing, painting, roofing, window frames, glazing, electrical, hydraulic, sewer, and fire systems. Thus, we chose to exclude these items because it does not influence the final result, which aims to compare the two systems.

The following items are excluded from the inventory, although forming part of the structure. At the foundation, only the beams are included. Piling, shallow or any other type of foundation is not considered. In the case would be very similar for the two proposals. This study analyzed the stages of production and transportation of materials, application in construction of building and waste removal. The stages of operation, maintenance and demolition were not counted during the work because it is considered to be fairly similar for both building systems and there are no policies in the region for recycling or final destination after demolition.

For the reinforced concrete structure we considered the following items: Foundation beams, and structure - pillars, beams, and slabs: this item included formwork, concrete and steel / Masonry: ceramic bricks and mortar / In the case of structural masonry structure, the following items were considered: Foundation beams, and structure slabs: included forms, concrete and steel / Masonry: structural walls composed of ceramic, mortar and steel.

\section{Energy embodied in materials}

As becomes very broad assessment of the total embodied energy, and due to some lack of databases needed for a complete analysis, some items were not encompassed, such as energy required for transportation of employees, production of energy for tools, production of energy (diesel and electricity), energy expended by cranes and elevators, among others. It is understood that there are not significant compared to what was included, besides being similar for both cases.

The materials used for the production of slabs and foundations, such as timber and steel are produced elsewhere and transported to the construction site, and there are benefited according to project needs. For example, crushed stone and cement are produced and transported to the Ready-Mixed Concrete Plants (RMCP), making dosing and delivery of concrete to work on concrete delivery trucks. Other materials such as timber and steel are produced and brought to the site directly.

Considering these peculiarities and elements from the literature, embodied energy values were taken from several references with preference to national data. Table 1 shows the energy values incorporated in the materials used in the buildings. The energy consumption includes the energy required for transportation. The materials considered are detailed below.

Portland cement: The manufacture of Portland cement involves a series of activities extending far tracking your entire production. In this case embodied energy to produce one ton of cement is around 6.0 GJ energy (Roaf et al., 2012; Scheuer et al., 2003; Tiwari, 2001; Venkatarama Reddy \& Jagadish, 2003). The origin of the cement used in these buildings is distant of $15 \mathrm{~km}$ of transport from the factory to the construction site.

Lime: The lime production consumes 5.6 GJ.ton ${ }^{-2}$ (Tavares, 2006; Venkatarama Reddy \& Jagadish, 2003). In this case, the source is to $150 \mathrm{~km}$ transport distance.

Sand: For this item was considered the energy consumed by river transport, as well as losses caused by the discharge of sand at the pier. The origin of the sand used is $40 \mathrm{~km}$ to work. The boat capacity is $100 \mathrm{~m}^{3}$, being powered by a diesel engine with an approximate consumption of $1 \mathrm{~km} / \mathrm{L}$, which runs on average $120 \mathrm{~km}$ on a full tour, with an average loss of around $1 \%$ on the

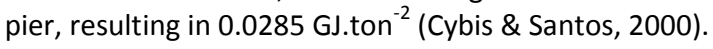

Crushed stone: We adopted the consumption of 0.15 GJ.ton ${ }^{-2}$ (Tavares, 2006). The origin of the raw material is located $18 \mathrm{~km}$ away from construction site.

Steel and derivatives: The steel used in buildings is provided by production unit that serves the area and is located $13 \mathrm{~km}$ away from construction site. For the production of steel in form of bars, it is necessary a consumption of $30 \mathrm{GJ} \cdot \mathrm{ton}^{-2}$. Already when it adopts recycling, using scrap as raw material, power consumption drops to $11.025 \mathrm{GJ}^{- \text {ton }^{-2}}$ (Gao et al. 2001; Roaf et al., 2012; Scheuer et al., 2003; Tiwari, 2001). Currently the provider foundry is using $70 \%$ waste for steelmaking. Thus, the

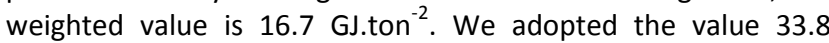
GJ.ton ${ }^{-2}$ to wires and 31.0 GJ.ton $^{-2}$ for nails, following Tavares (2006).

Formwork and shoring timber: Following several authors, estimated energy consumption for the production of timber is $1.5 \mathrm{GJ}^{\mathrm{tan}}{ }^{-2}$. The origin of the wood is an average distance of 60 $\mathrm{km}$ from sawmill to the construction site. The energy for timber for shores is $0.5 \mathrm{GJ}_{\text {.ton }}{ }^{-2}$. For the plywood were used $8.0 \mathrm{GJ}$.ton ${ }^{2}$. It is originate from the interior of Paraná state with a transport distance of 720 km (Gao et al., 2001; Roaf et al., 2012; Tavares, 2006).

Ceramic brick: The clay bricks have origin of own city of São Leopoldo, with an average distance of $10 \mathrm{~km}$ from fabric to site. Following the work of Manfredini \& Sattler (2005), to obtain the results of this item has been considered virtually all processes for producing bricks, resulting in $2.5236 \mathrm{GJ}$ ton $^{-2}$. 
Structural blocks: The company that produces the blocks is located $15 \mathrm{~km}$ away from work and it is the only fabric in the region that produces this type of block, with structural features. The data relating to the size and mass were obtained directly from the company's website, but the data on embodied energy were used following Manfredini \& Sattler (2005), with 2.5236 GJ.ton ${ }^{-2}$.

Transport: Road transport has a great importance in construction, because in Brazil all materials are transported by trucks. For this it was considered an average consumption of 3.0 $\mathrm{km} / \mathrm{L}$ to trucks used by the suppliers of cement, sand, crushed stone, timber, bricks and blocks, with a capacity of 5 tons per trip. The consumption of diesel followed the works of Cybis \& Santos (2000) and Manfredini \& Sattler (2005).

Mortar: Mortar is prepared on site, using mixer. The energy required for the mixing of materials is $0.0020 \mathrm{GJ} . t o n^{-2}$ (Roaf et al., 2012), and the energy for the production of materials is considered separately, as presented above.

Concrete: The production of concrete occurs on RMCP and the necessary materials as crushed stone, sand, cement, and water are transported to the production plant. This item considered energies for mixture at the plant and on drum mixer of delivery trucks, reaching 0.0025 GJ.ton $^{-2}$ (Roaf et al., 2012).

Transportation and concrete pumping: This item considered energy for transport ( $2 \mathrm{~km}$ from plant to site) and pumping, reaching 0.0050 GJ.ton $^{-2}$.

\begin{tabular}{|c|c|c|c|}
\hline Description & $\begin{array}{l}\text { Distance } \\
\text { to site (in } \\
\mathrm{km} \text { ) }\end{array}$ & $\begin{array}{l}\text { Density } \\
\text { (in kg.m }{ }^{-3} \text { ) }\end{array}$ & $\begin{array}{l}\text { Embodied } \\
\text { energy (in } \\
\text { GJ.ton }^{-2} \text { ) }\end{array}$ \\
\hline Cement & 15 & 1500 & 6.0 \\
\hline Lime & 150 & 1500 & 5.6 \\
\hline Sand & 40 & 1500 & 0.0285 \\
\hline Crushed stone & 18 & 1500 & 0.15 \\
\hline Steel - bar & 13 & 7800 & 16.7 \\
\hline Steel-wire & 13 & 7800 & 33.8 \\
\hline Steel-nails & 13 & 7800 & 31.0 \\
\hline Timber & 60 & 500 & 1.5 \\
\hline Timber-shores & 60 & 500 & 0.5 \\
\hline Plywood & 720 & 1000 & 8.0 \\
\hline Ceramic bricks $-10 \times 15 \times 20$ & 10 & 1700 & 2.5236 \\
\hline 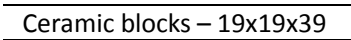 & 15 & 1500 & 2.5236 \\
\hline Transport/Diesel (by km) & - & - & 0.0010 \\
\hline $\begin{array}{l}\text { Collection/treatment and } \\
\text { distribution of water }\end{array}$ & 0 & 1000 & 0.0030 \\
\hline Production of mortar & 0 & 1250 & 0.0020 \\
\hline Production of concrete & 0 & 2300 & 0.0025 \\
\hline $\begin{array}{l}\text { Transport and pumping of } \\
\text { concrete }\end{array}$ & 2 & 2300 & 0.0050 \\
\hline
\end{tabular}

\section{Results}

In this section are compared qualitatively and quantitatively the two types of structures, to evaluate the results. For both structure types, concrete and structural masonry calculations and surveys of material were performed using structural engineering software. After calculation of each structure were calculated quantities of materials used therein.

Materials were measured in tones. For materials acquired in different measurement forms, such as sand, crushed stones, bricks and timber were used initially to measure the conventional unit, with quantities being converted by mass densities indicated in Table 1.

Embodied energy in building systems investigated is presented in Tables 2 and 3. Table 2 presents materials used for the implementation of concrete structure (including foundation and structure), which was considered a $15 \mathrm{MPa}$ concrete, and masonry wall required for execution of the project. The quantities of materials considering conventional waste (occurring within the construction site) for each type of service. For example, it was accounted $10 \%$ for brick waste (item 2.1) and $8 \%$ to steel (item 1.2.1). At the end, it was considered waste removal (item 3). In this item, the calculated energy is the activity of collection and removal of these materials suitable for landfills.

The parts considered of the building represent in total about $1,164 \mathrm{GJ}$ of embodied energy (EE) and 900 ton of mass (Table 2). In unitary figures, these results correspond to $1.72 \mathrm{GJ}^{-2}$ and 1.331 ton. $\mathrm{m}^{-2}$. As can be seen by figures in Table 2, about $66.5 \%$ of the energy used is incorporated in producing the ceramic bricks (item 2.1 of Table 2), and then appears cement which is responsible for about $18 \%$ of embodied energy (items 1.1 .1 and 2.2.1) and steel, with $9 \%$ (item 1.2.1). Waste, embedded in quantitative presented in Table 2 (item 3), represents about $10 \%$ of $E E$.

Table 3 presents materials needed for the implementation of structural masonry building. In this case the structure was divided into two groups, one for the foundation and for other to structural masonry. The table also incorporates waste, considering common rates of $2.5 \%$ for blocks (item 2.1 ).

The building composed of the structural masonry has a total energy consumption of $854 \mathrm{GJ}\left(1.26 \mathrm{GJ}^{-2} \mathrm{~m}^{-2}\right.$ ), and a total mass about 700 ton (1.035 ton. $\mathrm{m}^{-2}$ ), as reported in Table 3. The ceramic blocks are responsible for $65.7 \%$ of the embodied energy (item 2.1 of Table 3). Secondly, become cement, with 20.5\% of EE (item 1.1.1 and 2.2.1).

After results on Table 2 and 3, Figure 2 indicates embodied energy on main build materials, regarding each building system. 


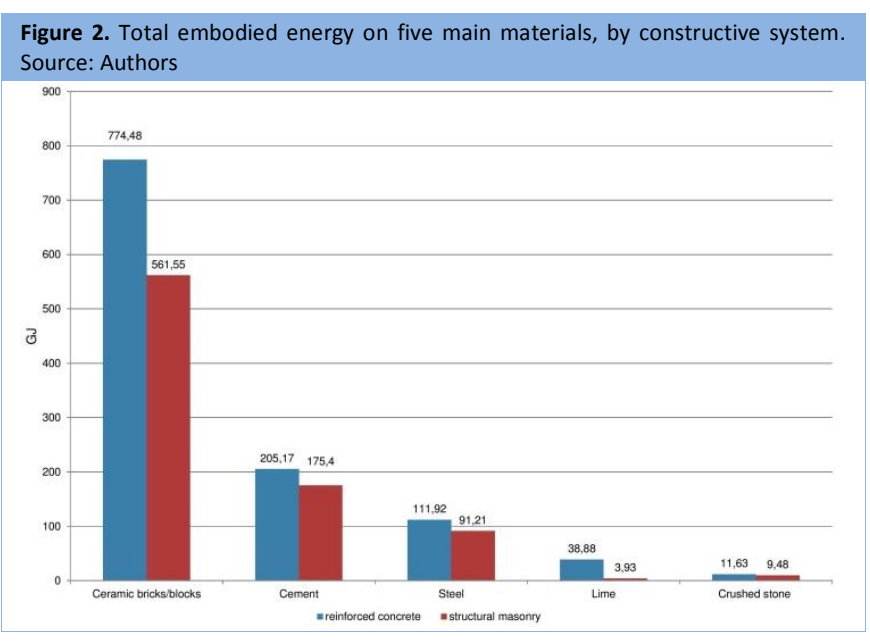

\begin{tabular}{|c|c|c|c|}
\hline Item & Description and basic quantities & $\begin{array}{l}\text { Material } \\
\text { - mass } \\
\text { (in ton) }\end{array}$ & $\begin{array}{l}\text { Embodied } \\
\text { energy } \\
\text { (in GJ)* }\end{array}$ \\
\hline 1. & Foundation beam and structure & & 302.81 \\
\hline 1.1 & Concrete $-86.5 \mathrm{~m}^{3}$ & & \\
\hline 1.1 .1 & Cement & 27.248 & 163.49 \\
\hline 1.1.2 & Sand & 72.868 & 2.08 \\
\hline 1.1 .3 & Crushed stone & 92.486 & 11.63 \\
\hline 1.1 .4 & Water & 12.845 & 0.04 \\
\hline 1.1 .5 & $\begin{array}{l}\text { Concrete-production and } \\
\text { application }\end{array}$ & 198.950 & 2.88 \\
\hline 1.2 & Reinforcement - 6.05 ton & & \\
\hline 1.2 .1 & Steel-bar & 6.534 & 109.20 \\
\hline 1.2 .2 & Steel-wire & 0.091 & 2.72 \\
\hline 1.3 & Beam formwork - $337.6 \mathrm{~m}^{2}$ & & \\
\hline 1.3 .1 & Plywood & 0.871 & 0.32 \\
\hline 1.3 .2 & Timber & 2.671 & 3.34 \\
\hline 1.3.3 & Shores. $\varnothing 10 \mathrm{~cm}(\mathrm{~h}=2.20 \mathrm{~m})$ & 1.697 & 0.11 \\
\hline 1.3 .4 & Nails & 0.084 & 2.53 \\
\hline 1.4 & Slab formwork - $660.0 \mathrm{~m}^{2}$ & & \\
\hline 1.4 .1 & Plywood & 1.505 & 0.55 \\
\hline 1.4 .2 & Timber & 0.990 & 1.24 \\
\hline 1.4 .3 & Shores. $\varnothing 10 \mathrm{~cm}(\mathrm{~h}=2.20 \mathrm{~m})$ & 9.953 & 0.70 \\
\hline 1.4 .4 & Nails & 0.066 & 1.98 \\
\hline 2. & Bricks masonry - $998.96 \mathrm{~m}^{2}$ & & 859.99 \\
\hline 2.1 & $\begin{array}{l}\text { Ceramic bricks }(0.14 \times 0.19 \times \\
0.09 \mathrm{~m})\end{array}$ & 305.682 & 774.48 \\
\hline 2.2 & Mortar - $38.082 \mathrm{~m}^{3}$ & & \\
\hline 2.2 .1 & Cement & 6.930 & 41.68 \\
\hline 2.2 .2 & Lime & 6.930 & 38.88 \\
\hline 2.2 .3 & Sand & 69.453 & 4.76 \\
\hline 2.2 .4 & Water & 4.615 & 0.0138 \\
\hline 2.2 .5 & $\begin{array}{l}\text { Mortar-production } \\
\text { application }\end{array}$ & 76.164 & 0.19 \\
\hline 3. & Waste remove - 94.821 ton & & 0.95 \\
\hline Total & & 898.631 & 1163.75 \\
\hline
\end{tabular}

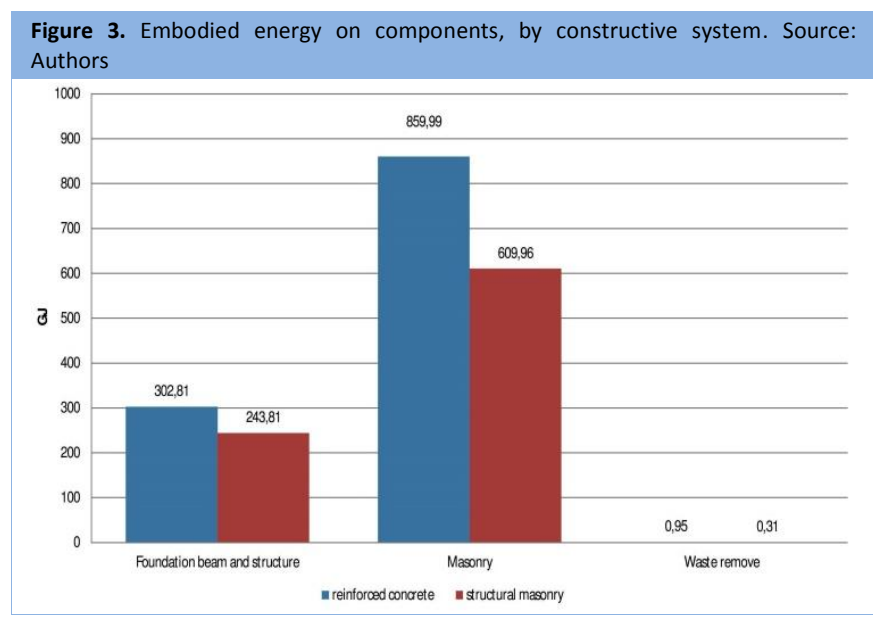

\begin{tabular}{|c|c|c|c|}
\hline Item & Description and basic quantities & $\begin{array}{l}\text { Material } \\
\text { - mass } \\
\text { (in ton) }\end{array}$ & $\begin{array}{l}\text { Embodied } \\
\text { energy } \\
\text { (in GJ)* }\end{array}$ \\
\hline 1. & $\begin{array}{l}\text { Foundation beams and structure; } \\
\text { includes structural masonry } \\
\text { mortars }\end{array}$ & & 243.81 \\
\hline 1.1 & Concrete $-70.5 \mathrm{~m}^{3}$ & & \\
\hline 1.1 .1 & Cement & 22.207 & 133.25 \\
\hline 1.1 .2 & Sand & 59.389 & 1.69 \\
\hline 1.1 .3 & Crushed stone & 75.379 & 9.48 \\
\hline 1.1 .4 & Water & 16.269 & 0.05 \\
\hline 1.1 .5 & $\begin{array}{l}\text { Concrete-production and } \\
\text { application }\end{array}$ & 176.250 & 2.56 \\
\hline 1.2 & Reinforcing - 4.93 ton & & \\
\hline 1.2 .1 & Steel-bar & 5.324 & 88.99 \\
\hline 1.2 .2 & Steel-wire & 0.074 & 2.22 \\
\hline 1.3 & Beam formwork $-60.0 \mathrm{~m}^{2}$ & & \\
\hline 1.3 .1 & Plywood & 0.155 & 0.06 \\
\hline 1.3 .2 & Timber & 0.475 & 0.59 \\
\hline 1.3 .3 & Shores. $\varnothing 10 \mathrm{~cm}(\mathrm{~h}=2.20 \mathrm{~m})$ & 0.302 & 0.02 \\
\hline 1.3 .4 & Nails & 0.015 & 0.45 \\
\hline 1.4 & Slab formwork - $660.0 \mathrm{~m}^{2}$ & & \\
\hline 1.4 .1 & Plywood & 1.505 & 0.55 \\
\hline 1.4 .2 & Timber & 0.990 & 1.24 \\
\hline 1.4 .3 & Shores. $\varnothing 10 \mathrm{~cm}(\mathrm{~h}=2.20 \mathrm{~m})$ & 9.953 & 0.70 \\
\hline 1.4 .4 & Nails & 0.066 & 1.98 \\
\hline 2. & Structural masonry $-1,206.72 \mathrm{~m}^{2}$ & & 609.96 \\
\hline 2.1 & Ceramic blocks & & \\
\hline 2.1 .1 & Full block $(0.14 \times 0.19 \times 0.29)$ & 162.966 & 413.71 \\
\hline 2.1 .2 & Half block $(0.14 \times 0.19 \times 0.14)$ & 4.491 & 11.40 \\
\hline 2.1 .3 & 11/2 Block $(0.14 \times 0.19 \times 0.44)$ & 18.838 & 47.82 \\
\hline 2.1 .4 & U Block $(0.14 \times 0.19 \times 0.29)$ & 34.910 & 88.62 \\
\hline 2.2 & Mortar - $19.31 \mathrm{~m}^{3}$ & & \\
\hline 2.2 .1 & Cement & 7.01 & 42.15 \\
\hline 2.2 .2 & Lime & 0.701 & 3.93 \\
\hline 2.2 .3 & Sand & 31.495 & 2.16 \\
\hline 2.2 .4 & Water & 5.133 & 0.0154 \\
\hline 2.2 .5 & $\begin{array}{l}\text { Mortar-production } \\
\text { application }\end{array}$ & 64.895 & 0.16 \\
\hline 3. & Waste remove -30.805 ton & & 0.31 \\
\hline Total & & 698.788 & 854.08 \\
\hline \multicolumn{4}{|c|}{ * Including transportation } \\
\hline
\end{tabular}




\section{Discussion and conclusion}

There is a difference of $0.46 \mathrm{GJ} . \mathrm{m}^{-2}$ in favor of the structural masonry (a reduction of more than $1 / 4$ when compared to reinforced concrete option) to the analyzed items. If they added the services and materials that were not in the inventory life cycle, such as special foundations, coatings, flooring, fixtures, roof, etc., this percentage tends to decrease. However the difference on energy consumption remains, in absolute numbers. Figure 3 illustrate the differences after the components of the building systems.

Part of the difference between the systems is due to the masonry type, which arises from the coverage area of the ceramic block over the brick, while the participation of blocks and bricks are similar (both about 66\%). It happens that, while the assembly formed by a block and its corresponding wall fills an area of $600 \mathrm{~cm}^{2}(20 \times 30 \mathrm{~cm})$ and has a mass of $6.5 \mathrm{~kg}$, a ceramic brick occupies an area of $200 \mathrm{~cm}^{2}$ and has a mass of 2.7 $\mathrm{kg}$ under similar conditions $(10 \times 20 \mathrm{~cm})$. Thus, for the same occupied area filled by the ceramic block, it is necessary to use 3 ceramic bricks, which together add up to a mass of $8,1 \mathrm{~kg}$, namely, $1.6 \mathrm{~kg}$ heavier than the mass of a block.

The quantity of mortar needed for ceramic tile is superior to the block, because the brick is used throughout complete seal around it. Furthermore, it is necessary to do more horizontal and vertical layers due to the smaller size of the ceramic tile. In the structural block is only necessary to make two horizontal and two vertical joints shaped fillet, so that the voids on blocks are not filled. The quantity of mortar in the masonry structural system is about $50 \%$ of the bricks masonry.

Another advantage observed for the use of ceramic blocks which may be used to calculate structure is reducing loads in structure and foundations due to the difference in mass of the blocks with respect to brick, as well as reducing the amount of mortar needed to execution. But often this advantage is no longer used because there are Brazilian standards which set values for each type of loading which in the case of hollow bricks or blocks is equal to $13 \mathrm{kN} \cdot \mathrm{m}^{-3}$. As a negative aspect, structural masonry presents an impossibility to change inner layout of the apartments, because it is not economically viable to make openings for doors, windows or remove walls. This characteristic decreases its ability to make changes in the building (flexibility for future use). This study indicated that the embodied energy in these two building systems is approximately $1.72 \mathrm{GJ}^{-2} \mathrm{~m}^{-2}$ and 1.26 GJ. $\mathrm{m}^{-2}$, respectively. It is concluded that the embodied energy is smaller in the structured masonry system, with a reduction of $26.7 \%$ relative to reinforced concrete option. The results can be used to aid design decisions. Considering the presented results, one can conclude that the building using structured masonry is advantageous from the environmental point of view, in respect of embodied energy by the amount of material required.

\section{Acknowledgements}

The authors wish to thank to Brazilian' Research Councils CAPES, CNPq and FAPERGS, and to UNISINOS to support the development of this project.

\section{References}

Asif, M., Muneer, T., \& Kelley, R. (2007). Life cycle assessment: a case study of a dwelling home in Scotland. Building and Environment, 42 (3), 1391-1394. doi:10.1016/j.buildenv.2005.11.023

Chel, A. \& Tiwari, G. N. (2009). Thermal performance and embodied energy analysis of a passive house - case study of vault roof mud-house in India. Applied Energy, 86(10), 1956-1969. doi:10.1016/j.apenergy.2008.12.033

Cybis, L. F. \& Santos, C. V. J. (2000). Análise do ciclo de vida (ACV) aplicada à indústria da construção civil. XXVII Congresso Interamericano de Engenharia Sanitária e Ambiental in Porto Alegre, Brasil.

Gao, W., Ariyama, T., Ojima, \& T., Meier, A. (2001). Energy impacts of recycling disassembly material in residential buildings. Energy and Buildings, 33(6), 553-562. doi:10.1016/50378-7788(00)00096-7

Gauzin-Müller, D. (2002). Sustainable Architecture and Urbanism: Concepts, technologies, examples. Basel, Belgium: Birkhäuser.

Manfredini, C. \& Sattler, M. A. (2005). Estimativa de energia incorporada a materiais de cerâmica vermelha no Rio Grande do Sul. Ambiente Construído, 5(1), 23-37.

Muñoz, C., Zaror, C., Saelzer, G., \& Cuchí, A. (2012). Estudio del flujo energético en el ciclo de vida de una vivienda y su implicancia en las emisiones de gases de efecto invernadero, durante la fase de construcción Caso Estudio: Vivienda Tipología Social. Región del Biobío, Chile. Revista de la construcción, 11(3), 125-145. doi:10.4067/S0718-915X2012000300011

Roaf, S., Fuentes, M. \& Thomas, S. (2012). Ecohouse: A design guide. $4^{\text {th }}$ ed. Oxford: Architectural Press/Elsevier.

Scheuer, C., Keoleian, G.A. \& Repper, P. (2003). Life cycle energy and environmental performance of a new university building: modelling challenges and design implications. Energy and Buildings, 35(10), 1049-1064. doi:10.1016/S0378-7788(03)00066-5

Taborianski, V. M. \& Prado, R. T. A. (2004). Comparative evaluation of the contribution of residential water heating systems to the variation of greenhouse gases stock in the atmosphere. Building and Environment, 39(6), 645-652 doi:10.1016/.buildenv.2003.12.007

Tavares, S. F. (2006). Metodologia para análise do ciclo de vida energético de edificações residenciais brasileiras, Tese de Doutorado, Universidade Federal de Santa Catarina, Florianópolis, Brasil [Thesis in portuguese].

Thormark, C. (2002). A low energy building in a lifecycle - Embodied energy, energy need for operation and recycling potential. International Journal of Building Environment, 37(4), 429435. doi:10.1016/S0360-1323(01)00033-6

Tiwari, P. (2001). Energy efficiency and building construction in India. Building and Environment, 36(10), 1127-1135. doi:10.1016/S0360-1323(00)00056-1

Venkatarama-Reddy, B. V. \& Jagadish, K. S. (2003). Embodied energy of common and alternative building materials and technologies. Energy and Buildings, 35(2), 129-137. doi:10.1016/S03787788(01)00141-4 